\title{
Evaluation of oil sands resources A case study in the Athabasca Oil Sands, NE Alberta, Canada
}

\author{
Yin Pengfei ${ }^{*}$, Liu Guangdi ${ }^{1}$, Liu Yingqi ${ }^{2}$, Liu Chenglin ${ }^{1}$ and Liu Wenping ${ }^{1}$ \\ ${ }^{1}$ College of Geoscience, China University of Petroleum, Beijing 102249, China \\ ${ }^{2}$ Sinocanada Petroleum Corp., Canada
}

(C) China University of Petroleum (Beijing) and Springer-Verlag Berlin Heidelberg 2013

\begin{abstract}
Oil sands are the most important of the oil and gas resources in Canada. So the distribution and evaluation of oil sands form a critical basis for risk investment in Canada. Distribution of oil sands resources is severely controlled by the reservoir heterogeneity. Deterministic modeling is commonly used to solve the heterogeneity problems in the reservoir, but rarely used to evaluate hydrocarbon resources. In this paper, a lithofacies based deterministic method is employed to assess the oil sands resources for a part of a mining project in northern Alberta. The statistical analysis of Dean Stark water and oil saturation data and study of the core description data, regional geology and geophysical logs reveal that the lithofacies in the study area can be classified into reservoir facies, possible reservoir facies and non-reservoir facies. The indicator krigging method is used to build a 3D lithofacies model based on the classification of sedimentary facies and the ordinary krigging method is applied to petrophysical property modeling. The results show that the krigging estimation is one of the good choices in oil sand resources modeling in Alberta. Lithofacies-grade based modeling may have advantages over the grade-only based modeling.
\end{abstract}

Key words: Athabasca oil sands, deterministic method, krigging method, 3D lithofacies model

\section{Introduction}

Oil sands are the most important of the oil and gas resources in Canada (Carrigy and Kramers, 1973; Flach, 1984; Hein and Cotterill, 2006a, 2006b; Mossop, 1980; Ranger, 1994; Vigrass, 1968; Wightman et al, 1995). According to the Alberta Energy Department in 2009, the oil sands resources in situ are 1.7 trillion barrels of bitumen and the proven reserves are 170.4 billion barrels in northern Alberta. About 20\% of bitumen resources occur in the surface mineable area ${ }^{\circledR}$. Oil sands are produced from the lower Cretaceous McMurray Formation, in which the depositional environments were typical delta plains (Flach and Mossop, 1985; Ranger and Gingras, 2003). The timing of oil accumulated was earlier than oil sands resource forming (Riediger et al, 2001; Bekele et al, 2002), and biodegradation of pre-existing petroleum created the oil sands resource (Allan and Creaney, 1991; Brooks et al, 1988; Hein and Langenberg, 2003; Moshier and Waples, 1985; Mossop and Flach, 1983; Riediger et al, 2001; Rubinstein and Strausz, 1979). The distribution of the oil sands resources is severely controlled by the reservoir heterogeneity (Brekke and Evoy, 2004; MacGillivray et al, 1992; Langenberg et al, 2002; Smith, 1989). Understanding of the spatial distribution of ore

*Corresponding author. email: pfyin.sipc@sinopec.com Received September 29, 2011 and waste is the key to the mining engineering plan and design and 3D oil sands resource modeling can help understand the distribution $^{(2)}$ (Langenbergetal et al, 2001). Various types of modeling methods have been proposed for bitumen resource mining assessment. The modeling method we used here is a deterministic interpolation method by integrating lithofacies and bitumen grade (porosity and oil saturation). We chose a small area of about 15 sections in the Northern Lights Partnership Property for this study. This paper summarizes the method and geological analysis of oil sands resources in the study area. The hard data available for this study include core description data, Dean Stark data and geophysical log data $^{\circledR}$. The Northern Lights project area is located about 110 kilometers northeast of Fort McMurray in Township 98 and 99, Ranges 5 to 7 W4M (west of the Fourth Meridian) and the study area is situated in the west lease of the project area $\oplus$ (Fig. $1)$.

\footnotetext{
(1) http://www.energy.alberta.ca/OilSands/791.asp

(2) Alberta Energy and Utilities Board. Phase 3 final proceeding under bitumen conservation requirements in the Athabasca WabiskawMcMurray. Decision 2005-B(122): 32

${ }^{3}$ Paulen R, Rice R and Gingras M. Geology of the Fort McMurray area, northeast Alberta. Edmonton Geol. Society (Edmonton). 2004: 67

${ }^{\oplus} \mathrm{http}: / /$ www.cspg.org/conventions/abstracts/2005Core/kimball_e despositional_environments. pdf
} 


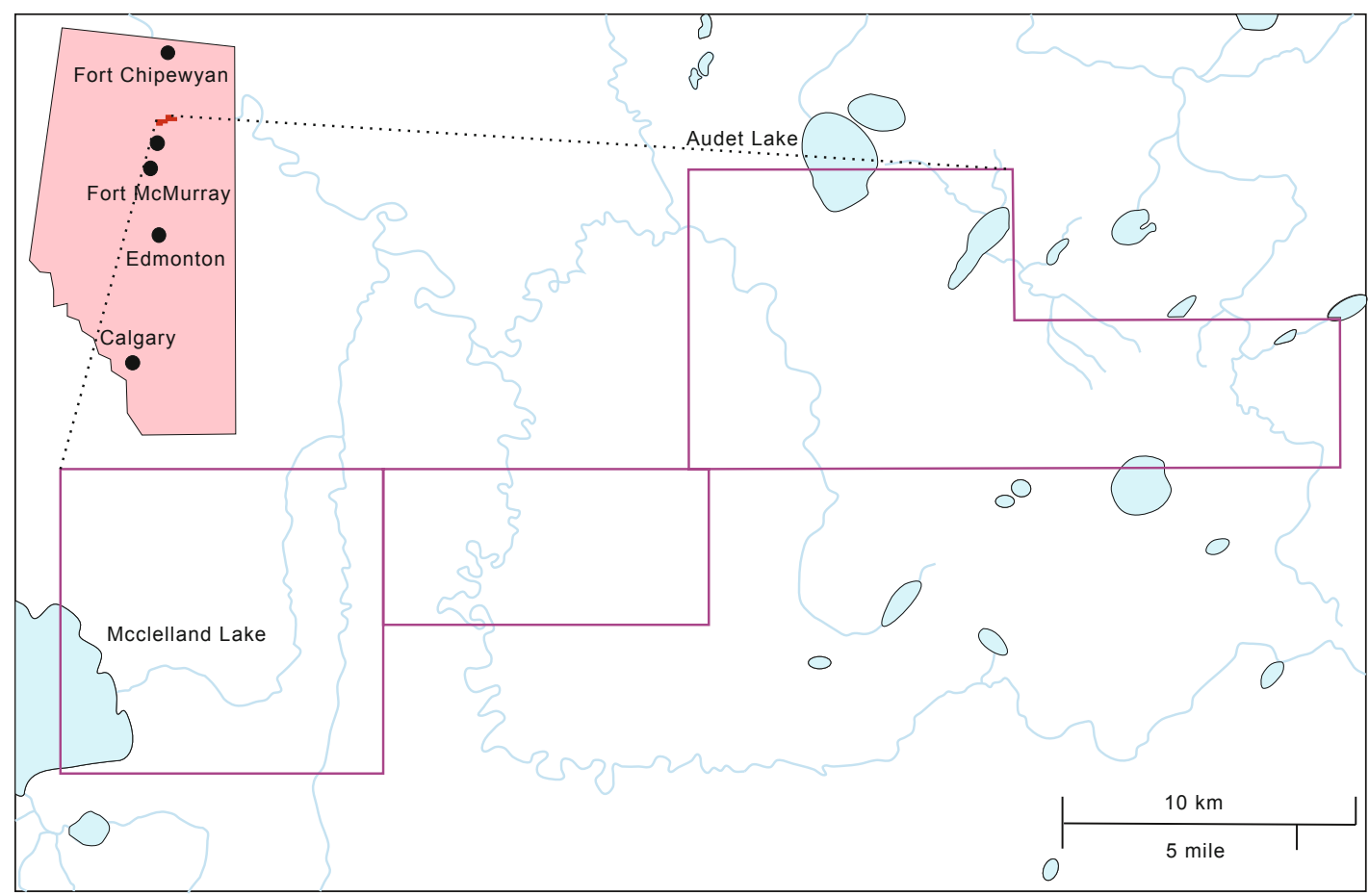

Fig. 1 Location of the study area

(Modified from http://environment.alberta.ca/documents/Synenco_Energy_Northern-Lights-Oil-Sands-Mine_PDD.pdf)

\section{Oil sands geology in Northern Lights Project Leases}

In the study area, oil sands occur dominantly in the Middle and Lower McMurray Formations, which were deposited in estuarine-tidal-fluvial depositional systems (Alberta Energy and Utilities Board, 2003; Flach and Hein, 2001; Hein and Cotterill, 2006a; 2006b). The estuarine channel sand, tidal channel sand, tidal flat sand, and fluvial channel sand serve as the major oil sands reservoirs. Typically Middle McMurray's upper estuarine sands are well sorted thickly bedded fine to medium grained sheet sand and sand beds are generally on a meter scale. Lower estuarine sands are composed of well sorted fine-medium grained sands with interbedded tidal muds. Tidal flat deposits consist of thin well sorted, fine grained flat sand, flat muds and mixture of fine grained flat sand and muds. Mud breccia was deposited in association with the Middle McMurray estuarine and tidal channel sands. Early fluvial sands are coarse sands deposited in a high energy environment. Late fluvial deposits consist of moderately sorted, fine-medium grained sands. Marsh muds and the associated coal swamp low energy clays, silts and coaly deposits are also developed in Lower McMurray (Hein and Dolby, 2001; Hein et al, 2000).

\section{Classification of lithofacies}

Based on the study of depositional environments, core data, statistical analysis of Dean Stark data, geophysical $\log$ data and the facies associations in cross-sections, the sedimentary facies can be categorized into differenst facies groups in the Middle and Lower McMurray Formations (Table 1).

The reservoir facies group is chiefly composed of sand lithofacies deposited in the tidal/estuarine channel (the Middle McMurray Formation) and the continental fluvial channel (the Lower McMurray Formation). The possible reservoir facies group consists of sand dominated, sand/mud mixed facies and sand/mud breccia mixed facies deposited in the tidal flat or the continental overbank; while the non-reservoir facies group includes the mud/coal dominated facies, the sand facies deposited in the marsh, coal swamp, overbank and tidal flats. Fine-medium grained channel sand (Fig. 2) and tidal/ estuarine channel sand (Fig. 3) are the best and typical oilsands reservoirs in Northern Lights Partnership leases.

\section{Data analysis}

Statistical analysis of Dean Stark data indicates that the lithofacies classification of reservoirs, possible reservoirs, and non-reservoirs is well reflected by the bitumen content (Table 2 ). The average content of bitumen in reservoirs is generally well above cut-off grade $(6 \%)$. That of the possible reservoirs is around the cut-off grade and that of the non-reservoir is well below the cut-off grade. The bitumen contents are generally high in reservoir facies (Fig. 4). For this modeling, we should determine the distribution of the reservoir facies and the possible reservoir facies, of which the bitumen grade is above the cut-off grade (Hein and Cotterill, 2006a; 2006b; Hein et al, 2006). 
Table 1 Classification of facies groups in the Lower and Middle McMurray Formations

\begin{tabular}{|c|c|c|c|c|c|}
\hline Member & Facies group & Facies & Brief description & Depositional environment & $\begin{array}{r}\text { Bitumen } \\
\text { content }\end{array}$ \\
\hline \multirow{9}{*}{$\begin{array}{c}\text { Middle } \\
\text { McMurray } \\
\text { Formation }\end{array}$} & \multirow{2}{*}{$\begin{array}{l}\text { Reservoir } \\
\text { facies }\end{array}$} & $\begin{array}{l}\text { Estuarine channel } \\
\text { sand }\end{array}$ & $\begin{array}{l}\text { Fine-medium grained, well sorted sand with } \\
\text { low-angle cross beddings }\end{array}$ & Estuarine & $>6 \%$ \\
\hline & & Tidal channel sand & $\begin{array}{l}\text { Dominantly fine grained, well sorted sand with } \\
\text { low-angle cross beddings, and few burrows }\end{array}$ & Tidal channel & $>6 \%$ \\
\hline & \multirow{2}{*}{$\begin{array}{l}\text { Possible } \\
\text { reservoir } \\
\text { facies }\end{array}$} & Silt/sand flat & $\begin{array}{l}\text { Silt/very fine-fine grained sand with interbedded/ } \\
\text { interlaminated mud, moderately bioturbated }\end{array}$ & Tidal flat & $5 \%-8 \%$ \\
\hline & & Channel breccia & $\begin{array}{l}\text { Fine-medium grained sand with greater than } \\
\qquad 10 \% \text { mud breccia, chaotic }\end{array}$ & Tidal/estuarine channel & $6 \%-10 \%$ \\
\hline & \multirow{5}{*}{$\begin{array}{l}\text { Non-reservoir } \\
\text { facies }\end{array}$} & Mud flat & $\begin{array}{l}\text { Thick mud with interlaminated very fine-fine } \\
\text { grained sand/silt }\end{array}$ & Tidal flat & $<4 \%$ \\
\hline & & Mixed flat & $\begin{array}{l}\text { Interbedded/interlaminated very fine-fine grained sand } \\
\text { and mud, intensively bioturbated }\end{array}$ & & \\
\hline & & $\begin{array}{l}\text { Abandoned channel } \\
\text { mud }\end{array}$ & Thick mud with interbedded thin fine grained sand & & \\
\hline & & Estuarine channel sand & $\begin{array}{l}\text { Fine-medium grained, well sorted sand with } \\
\text { low-angle cross beddings }\end{array}$ & Estuarine channel & $<6 \%$ \\
\hline & & Tidal channel sand & $\begin{array}{l}\text { Dominantly fine grained, well sorted sand with } \\
\text { low-angle cross beddings, and few burrows }\end{array}$ & Tidal channel & $<6 \%$ \\
\hline \multirow{11}{*}{$\begin{array}{l}\text { Lower } \\
\text { McMurray } \\
\text { Formation }\end{array}$} & \multirow{2}{*}{$\begin{array}{l}\text { Reservoir } \\
\text { facies }\end{array}$} & $\begin{array}{l}\text { Fluvial channel } \\
\text { coarse sand }\end{array}$ & $\begin{array}{l}\text { Medium-very coarse grained, moderately sorted sand } \\
\text { with high-angle cross beddings }\end{array}$ & Fluvial channel & $>6 \%$ \\
\hline & & $\begin{array}{l}\text { Fluvial channel } \\
\text { fine sand }\end{array}$ & $\begin{array}{l}\text { Fine-medium-grained, moderately sorted sand with } \\
\text { high-angle cross beddings }\end{array}$ & Fluvial channel & $>6 \%$ \\
\hline & $\begin{array}{c}\text { Possible } \\
\text { reservoir } \\
\text { facies }\end{array}$ & Overbank sand/silt & Silty sand with mud layers & Overbank & $4-7 \%$ \\
\hline & \multirow{8}{*}{$\begin{array}{l}\text { Non-reservoir } \\
\text { facies }\end{array}$} & Overbank mixed & Interbedded fine grained sand and mud & & $<3 \%$ \\
\hline & & Pond mud & Thin bedded mud and silt mud & Pond & $<1 \%$ \\
\hline & & Marsh mud & Mud and silty mud, bedding disturbed by plant roots & Marsh & $<1 \%$ \\
\hline & & Coal swamp-coal & Coal, may include thin bedded mud & Coal swamp & $<1 \%$ \\
\hline & & Coal swamp margin & Coal, dark/dark brown carbonaceous mud & & $<1 \%$ \\
\hline & & & Fine to very coarse grained, moderately sorted sand with & & \\
\hline & & Fluvial channel sand & high-angle cross beddings & Fluvial channel & $<6 \%$ \\
\hline & & Post-depositional slump & $\begin{array}{l}\text { Mixed McMurray sediments, folded, faulted by } \\
\text { post-depositional slumping }\end{array}$ & Post-depositional slump & $<4 \%$ \\
\hline
\end{tabular}




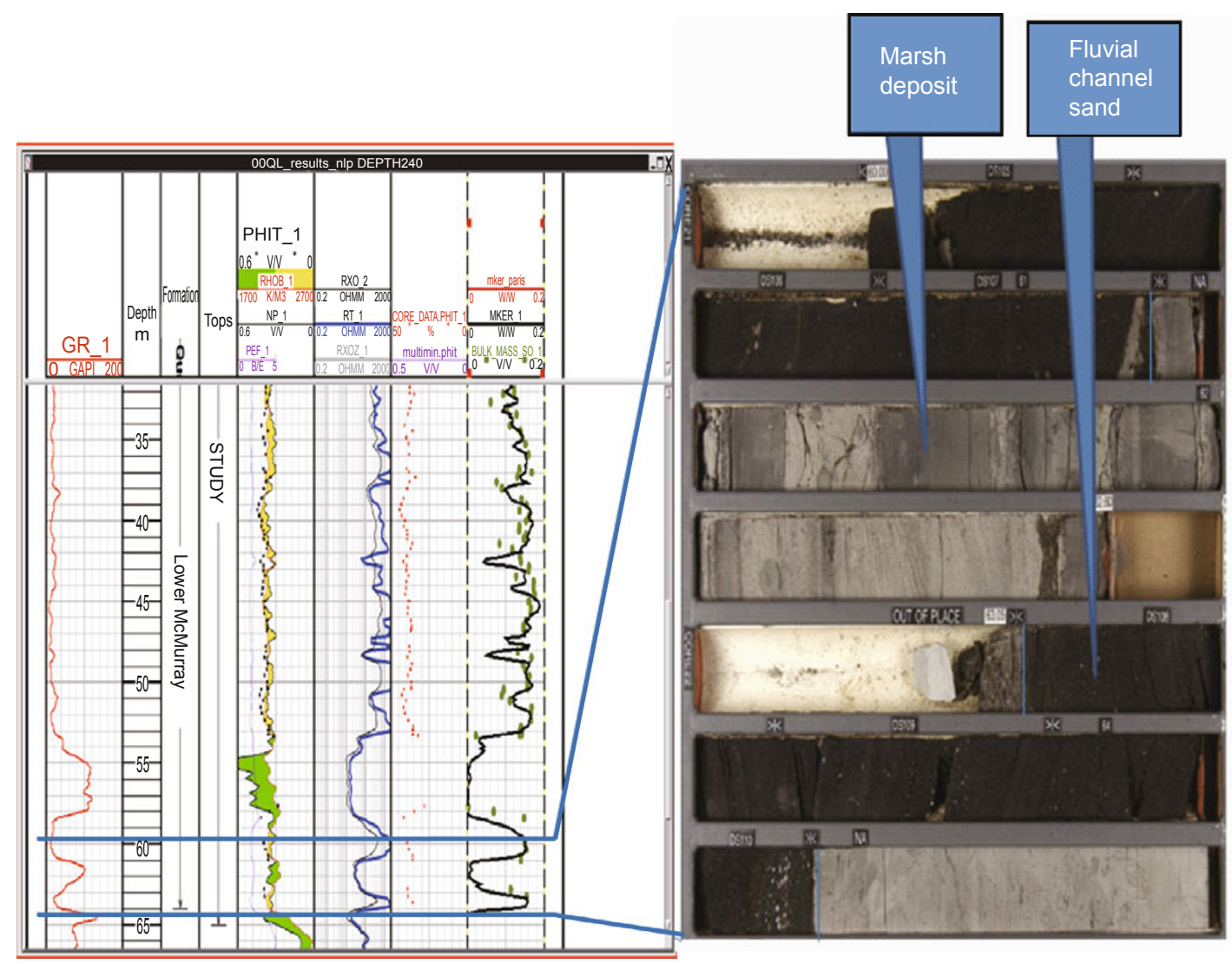

Fig. 2 Typical fluvial channel sand with high resistivity and low Gamma ray

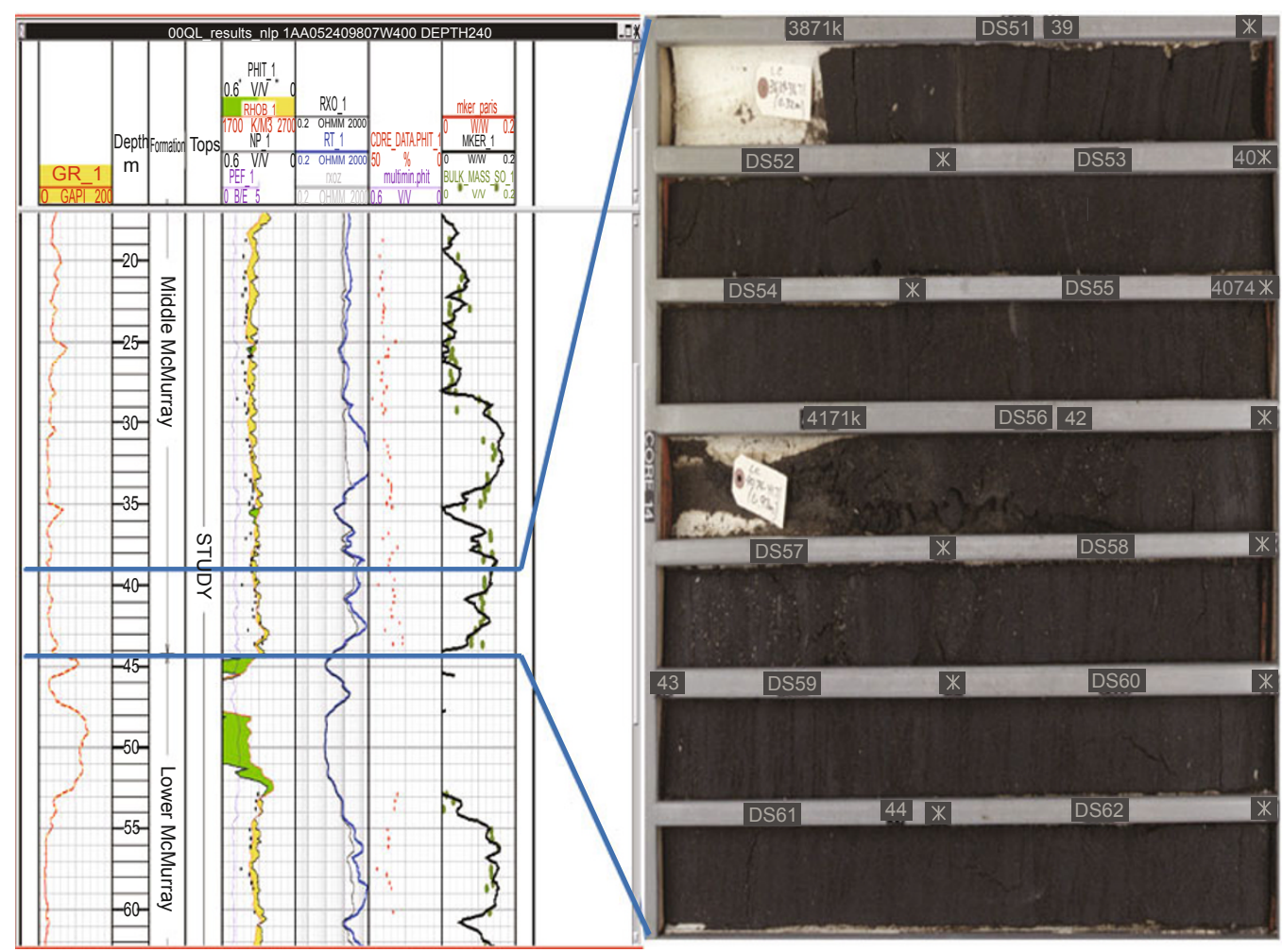

Fig. 3 Tidal and estuarine channel sand 
Table 2 Statistics on bitumen content

\begin{tabular}{|c|c|c|c|}
\hline \multirow{2}{*}{ Facies } & \multicolumn{3}{|c|}{ Bitumen content, $\%$} \\
\hline & Min. & Max. & Average \\
\hline Estuarine channel & 5.03 & 18.24 & 12.03 \\
\hline Estuarine channel sand & 0.27 & 4.92 & 2.74 \\
\hline Tidal channel sand & 5.00 & 19.59 & 12.81 \\
\hline Tidal channel sand & 0 & 4.98 & 3.09 \\
\hline Tidal/estuarine channel breccia & 0 & 17.65 & 6.49 \\
\hline Abandoned tidal channel & 0.01 & 3.02 & 0.69 \\
\hline Tidal flat sand & 0.24 & 17.95 & 7.87 \\
\hline Tidal flat sand & 1.35 & 2.93 & 2.25 \\
\hline Tidal flat mixed & 0 & 8.98 & 3.32 \\
\hline Tidal flat mud & 0 & 4.90 & 1.09 \\
\hline Fluvial channel coarse sand & 5.02 & 17.98 & 11.07 \\
\hline Fluvial channel coarse sand & 0.02 & 12.66 & 2.86 \\
\hline Fluvial channel fine sand & 5.00 & 18.61 & 11.36 \\
\hline Fluvial channel fine sand & 0 & 7.26 & 2.82 \\
\hline Overbank sand & 0 & 17.29 & 5.75 \\
\hline Flood plain & 0 & 8.89 & 2.50 \\
\hline Marsh & 0.01 & 2.60 & 0.57 \\
\hline Coal swamp & 0 & 4.18 & 0.94 \\
\hline
\end{tabular}
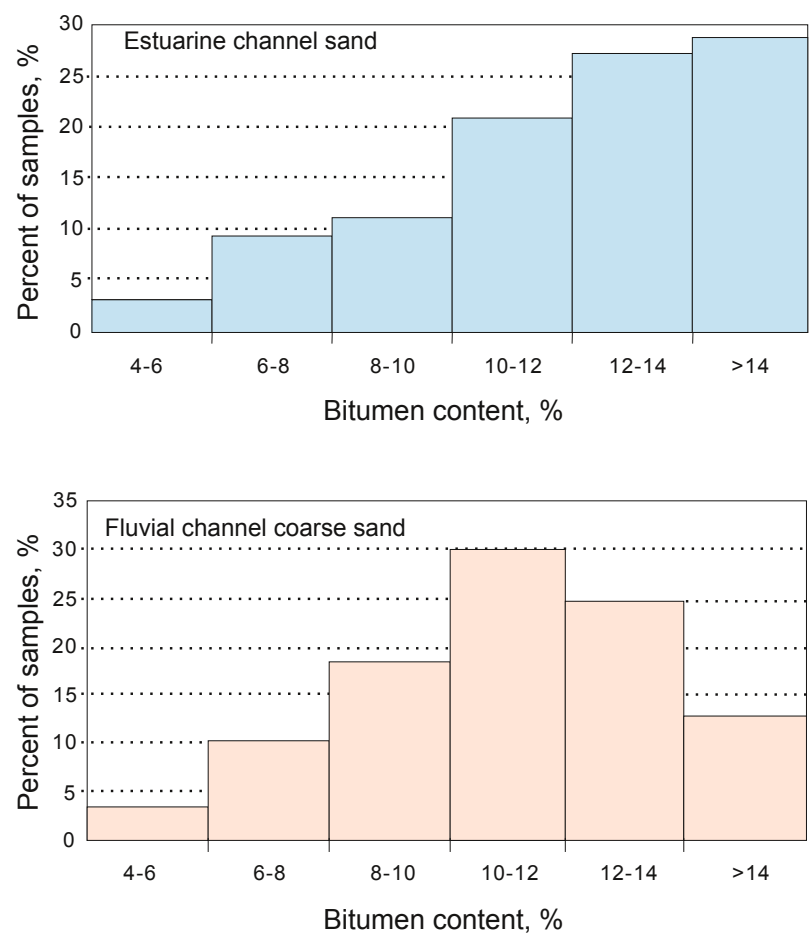

In the Middle McMurray Formation, the average reservoir accounts for more than $50 \%$ of the total rocks; while the reservoirs occur mainly at the top and the bottom in the Lower McMurray Formation (Fig. 5).

\section{Resources modeling method}

Deterministic methods and stochastic methods are generally used in oil and gas resources and reservoir modeling depending on the data available. The stochastic methods, such as sequential Gaussian simulation, are employed in the areas with sparse data. However, the deterministic methods are generally considered in the areas with plenty of data available for modeling. In our study area, the well spacing is less than 100 meters in some parts and more than 260 holes were drilled. In this case, it is believed that the deterministic method is a good choice for resources modeling. For facies modeling, the indicator krigging method is used and the ordinary krigging estimator is employed to interpolate the bitumen grade on the basis of facies modeling.

\subsection{The method}

In the indicator krigging interpolation of lithofacies and the ordinary krigging estimation of reservoir petrophysical properties, semivariograms, functions indicating the spatial correlation in observations measured at sample locations, should be calculated and the appropriate semivariogram model should be selected for modeling both lithofacies and reservoir petrophysical properties.

\subsubsection{Semivariogram}

Semivariogram is defined as (Clark, 2001):

$$
\gamma(h)=\frac{1}{2 N(h)} \sum_{i}^{N(h)}\left(Z\left(x_{i}\right)-Z\left(x_{i+h}\right)\right)^{2}
$$
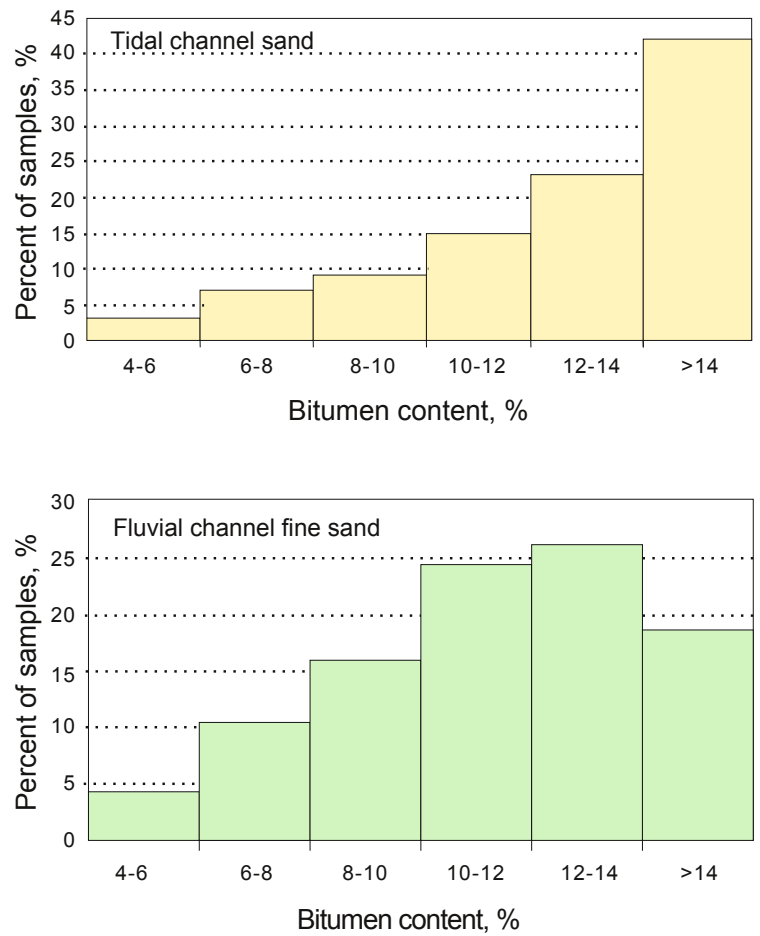

Fig. 4 Bitumen content distribution in reservoir samples 


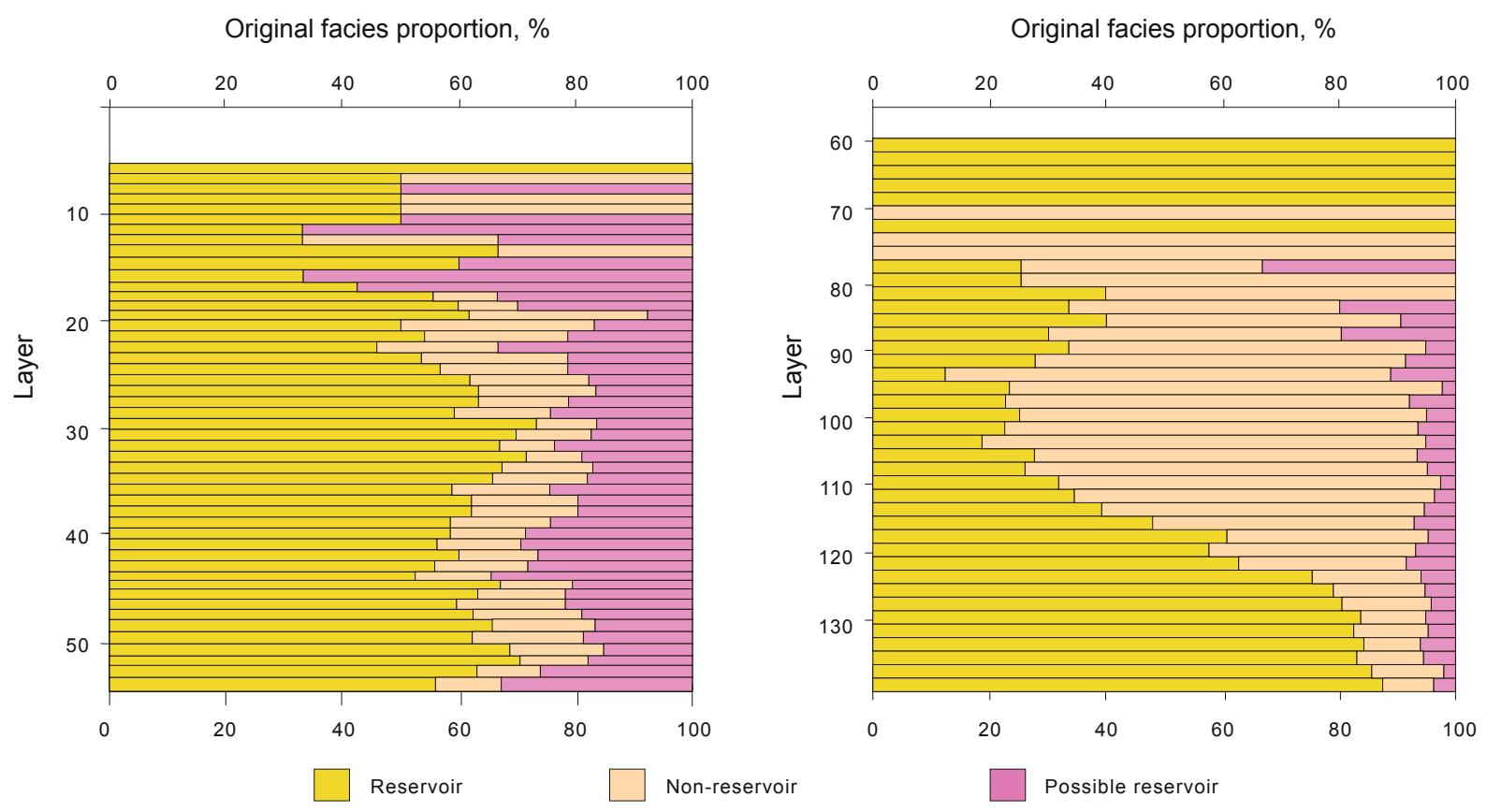

Fig. 5 Vertical distribution of the reservoirs in the Middle (left) and Lower (right) McMurray Formation

where $\gamma\left(x_{i}, x_{j}\right)$ is the semivariogram; $N(h)$ is the number of data pairs separated by distance of $h ; Z\left(x_{i}\right)$ is the value at the start or "tail" of the pair and $Z\left(x_{i}+h\right)$ is the variable at the end or "head" of the pair. The formula above can be used for continuous data and discrete data. However, it is called an indicator semivariogram, where the indicator is used instead of the property values in the formula above.

\subsubsection{Semivariogram models}

There are many semivariogram models in practice. However, the most common ones are spherical, exponential and straight line models. Nugget, range and sill parameters are important for semivariogram models. However, the straight line model does not have sill and range (Clark, 2001).

\subsubsection{Indicator semivariogram}

An indicator is used in the calculation of indicator semivariograms and is defined as follows:

$$
I\left(x_{i}, s_{k}\right)=\left\{\begin{array}{cc}
1 & Z\left(x_{i}\right)=s_{k} \\
0 & \text { otherwise }
\end{array} \quad k=1,2, \cdots, K\right.
$$

where $x_{i}$ is a vector representing a particular facies location; $k$ is the presence of a particular facies.

If the particular facies is present at location $x_{\mathrm{i}}$, its indicator is assigned to 1 ; otherwise, it is 0 . For the indicator semivariogram, $Z\left(x_{i}\right)$ and $Z\left(x_{i}+h\right)$ are replaced by $I\left(x_{i}, s_{k}\right)$ and $I\left(x_{i}+h, s_{k}\right)$ in the semivariogram formula above.

\subsubsection{Ordinary krigging method}

Ordinary krigging estimation is one of the methods in the krigging estimation family and it uses the local average value to estimate the particular property. The formula is defined as:

$$
\hat{Z}\left(x^{*}\right)=\left[\begin{array}{c}
\lambda_{1} \\
\cdot \\
\cdot \\
\cdot \\
\lambda_{n}
\end{array}\right] \cdot\left[\begin{array}{c}
Z\left(x_{i}\right) \\
\cdot \\
\cdot \\
\cdot \\
Z\left(x_{n}\right)
\end{array}\right]
$$

$\hat{Z}\left(x^{*}\right)$ is the krigging estimator, $Z\left(x_{i}\right)(i=1,2, \cdot, n)$ is grade value at location $x_{i}$. The weight vector $(\lambda)$ is determined as follows:

$$
\left[\begin{array}{c}
\lambda_{1} \\
\cdot \\
\cdot \\
\lambda_{n} \\
\mu
\end{array}\right]=\left[\begin{array}{ccccc}
\gamma\left(x_{1}, x_{2}\right) & \cdots & \cdots & \gamma\left(x_{1}, x_{n}\right) & 1 \\
\vdots & \vdots & \vdots & \vdots & \vdots \\
\vdots & \vdots & \vdots & \vdots & \vdots \\
\gamma\left(x_{n}, x_{1}\right) & \cdots & \cdots & \gamma\left(x_{n}, x_{n}\right) & 1 \\
1 & \cdots & \cdots & 1 & 0
\end{array}\right]^{-1}\left[\begin{array}{c}
\gamma\left(x_{1}, x^{*}\right) \\
\vdots \\
\vdots \\
\gamma\left(x_{n}, x^{*}\right) \\
1
\end{array}\right]
$$

where $\gamma\left(x_{i}, x_{j}\right)$ is the semivariogram of the property $Z$, which is separated by the distance between locations $x_{i}$ and $x_{j}$. The sum of $\lambda_{i}(\mathrm{i}=1,1,2, \cdot, n)$ should be 1 .

$$
\sum_{i=1}^{n} \lambda_{i}=1
$$

\subsection{Lithofacies modeling}

Indicator krigging is used to interpolate facies. An indicator semivariogram is calculated for reservoir facies, possible reservoir facies and non-reservoir facies in the Middle McMurray and Lower McMurray Formation. The variograms match the spherical variogram model. For the indicator variograms, they match the spherical model very well (Table 3 and Fig. 6 upper).

The nuggets are generally high for the reservoir facies in the study area, indicating high variability of reservoir facies in the study area. The ranges in the major and minor directions are quite different in both the Middle and Lower McMurray Formations, implying the fluvial channel, estuarine and tidal channel depositional environments of the reservoir. After the semivariogram is computed, indicator krigging is employed to interpolate lithofacies.

\subsection{Reservoir property modeling}

The semivariogram of bitumen content is calculated 
Table 3 Calculated variogram parameters for the Middle McMurray and Lower McMurray reservoirs

\begin{tabular}{ccccc}
\hline Property & $\begin{array}{c}\text { Middle McMurray } \\
\text { reservoir facies }\end{array}$ & $\begin{array}{c}\text { Lower McMurray } \\
\text { reservoir facies }\end{array}$ & $\begin{array}{c}\text { Bitumen content in the Middle } \\
\text { McMurray reservoir facies }\end{array}$ & $\begin{array}{c}\text { Bitumen content in the Lower } \\
\text { McMurray reservoir facies }\end{array}$ \\
\hline Variogram model & Spherical & Spherical & Spherical & Spherical \\
Search radius, m & 2000 & 2000 & 2000 & 2000 \\
Lag distance, $\mathrm{m}$ & 266.7 & 266.7 & 266.7 & 266.7 \\
Tolerance angle, & 15 & 15 & 15 & 15 \\
Tolerance distance, $\%$ & 50 & 50 & 50 & 50 \\
Nugget & 0.726 & 0.468 & 0.517 & 0.554 \\
Major range, $\mathrm{m}$ & 627.5 & 1096.7 & 876.2 & 1029.4 \\
Minor range, $\mathrm{m}$ & 302.3 & 767.9 & 793.3 & 774.2 \\
Vertical range, $\mathrm{m}$ & 29.2 & 26 & 29.9 & 54.1 \\
\hline
\end{tabular}
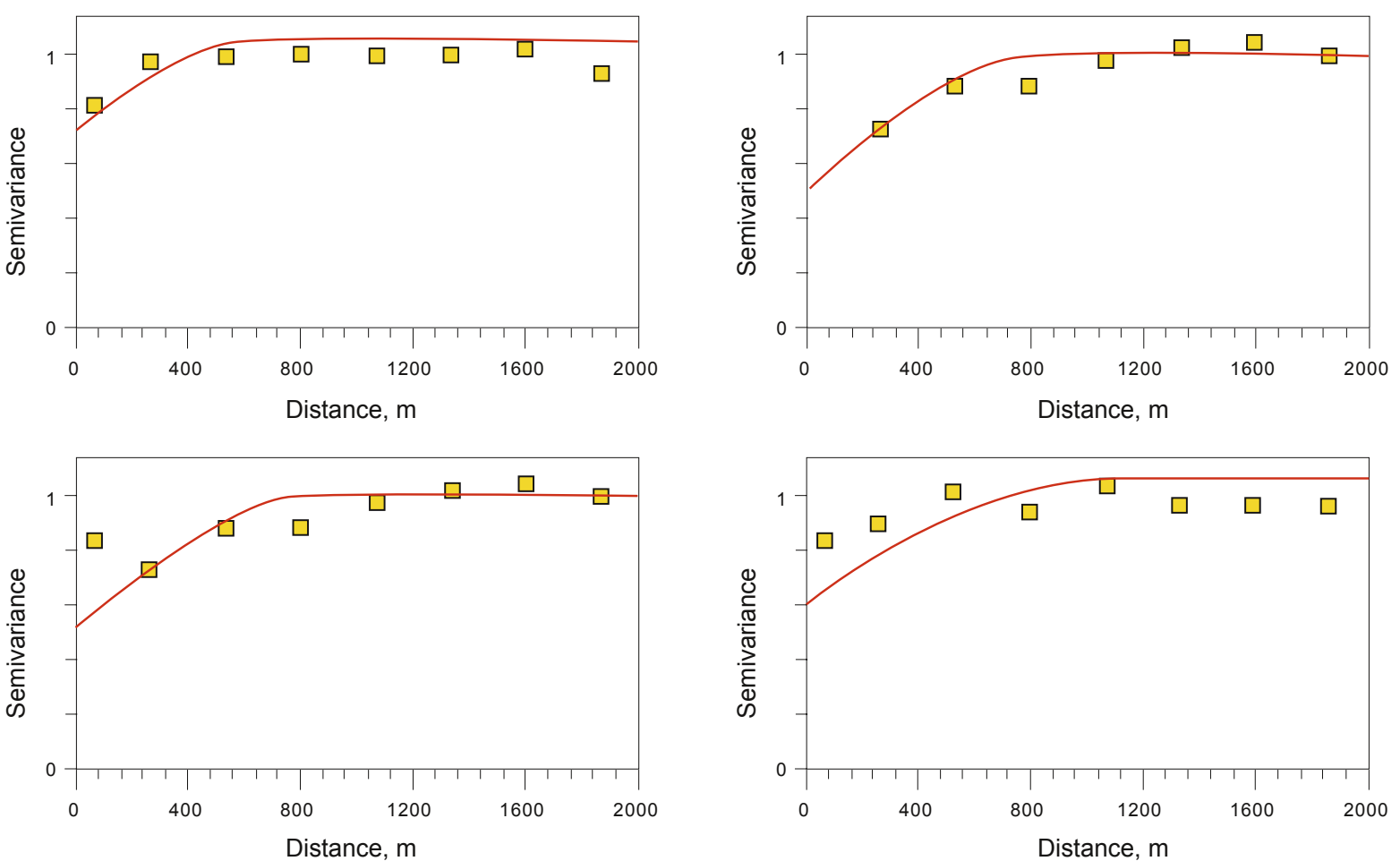

Fig. 6 Indicator variogram of reservoir facies (Upper left: Middle McMurray, Upper right: Lower McMurray), and bitumen content of the reservoirs (Bottom left: Middle McMurray, Bottom right: Lower McMurray)

for reservoirs, non-reservoirs and possible reservoirs in the Middle and Lower McMurray Formations. The spherical model seems to fit the semivariogram of the bitumen grade. Table 3 and Fig. 6 (bottom) show the semivariogram models of bitumen grade in the reservoir facies in the Middle and Lower McMurray Formations respectively. Again the nuggets are high, implying high variability in bitumen grade. The ordinary krigging method is used to interpolate the bitumen grade based on the semivariogram model.

Some modelers also use the inverse distance squared method in their resources modeling. They believe that krigging estimation may produce a more reasonable result if a lot of hard data are available. In addition, the Middle McMurray Formation and the Lower McMurray Formation is treated as two separate zones in both facies modeling and petrophysical modeling.

\section{Quality control of modeling results}

The facies distribution histogram (Fig. 7) and probability curves are calculated before and after modeling and a comparison between them shows a very good match before and after modeling.

\section{Discussion}

The krigging estimation is one of the good choices in oil sand resources modeling if the well space in the modeling area is small and lot of hard data (core logging, Dean Stark and geophysical log data) are available though the inverse distance squared method is extensively accepted as one of 


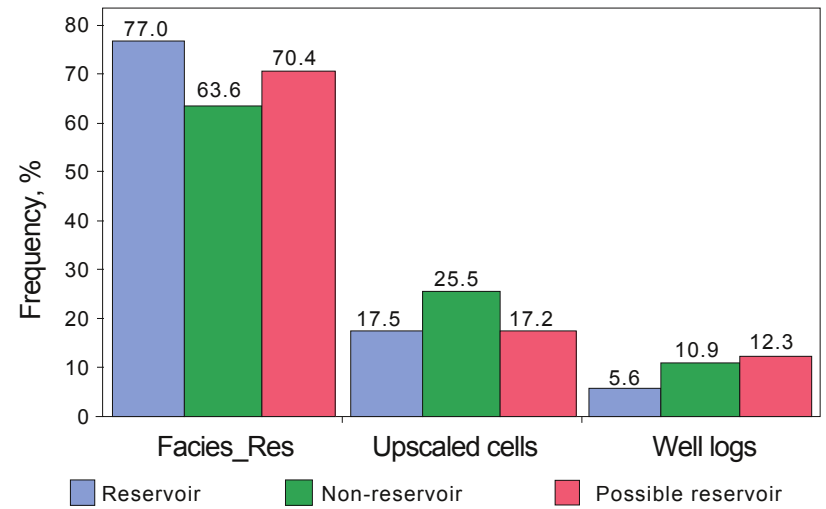

Fig. 7 Distribution histogram of facies after modeling

oil sands resources modeling method in Alberta. Lithofaciesgrade based modeling may have advantages over the gradeonly based modeling since the data used for estimation are sourced from the same or the similar sedimentary facies in lithofacies-grade based modeling.

\section{References}

Alberta Energy and Utilities Board. Athabasca Wabiskaw-McMurray regional geological study. Report. 2003-A. 188 (CD-ROM)

Allan J and Creaney S. Oil families of the Western Canada Basin. Bulletin of Canadian Petroleum Geology. 1991. 39: 107-122

Bekele E B, Person M A, Rostron B J, et al. Modeling secondary oil migration with core-scale data: Viking Formation, Alberta Basin. AAPG Bulletin. 2002. 86: 55-74

Brekke $\mathrm{H}$ and Evoy R. Use of dipmeter data in the definition of the internal architecture of point-bar deposits in the Athabasca oil sands: Implications for the Middle McMurray Formation in the Hangingstone area, Alberta (abs.). AAPG Annual Convention Abstracts. 2004. 13: A17

Brooks P W, Fowler M G and Macqueen R W. Biological marker and conventional geochemistry of oil sands/heavy oils, Western Canada Basin. Organic Geochemistry. 1988. 12: 519-538

Carrigy M A and Kramers J W. Guide to the Athabasca oil sands area. Information Series V., 65. Research Council of Alberta. AAPG Bulletin. 1973. 69: 213

Clark I. Practical Geostatistics. Geostokos Limited, Scotland. 2001. 68

Flach P D. Oil sands geology — Athabasca deposit north. Alberta Research Council Bulletin. 1984. 46: 31

Flach P D and Hein F J. Outcrop-core correlation of channel and non-channel facies, McMurray Formation, Fort MacKay Area, NE Alberta. Rock the Foundation Convention, Canadian Society of Petroleum Geologists (Calgary). 2001. 132-133

Flach P D and Mossop G D. Depositional environments of lower Cretaceous McMurray Formation, Athabasca oil sands, Alberta. American Association of Petroleum Geologists Bulletin. 1985. 69: 1195-1207

Hein F J and Cotterill D K. The Athabasca oil sands - A regional geological perspective, Fort McMurray Area, Alberta, Canada. Natural Resources Research. 2006a. 15: 85-102

Hein F J and Cotterill D K. Field guide: Regional sedimentology and processes of deposition of the Athabasca oil sands, NE Alberta. Alberta Energy and Utilities Board/Alberta Geological Survey. GeoNote. 2006b: 167 (CD-ROM)

Hein F J, Cotterill D K, Berhane H, et al. An atlas of lithofacies of the McMurray Formation, Athabasca oil sands deposit, northeastern Alberta: Surface and subsurface. Alberta Energy and Utilities Board/
Alberta Geol. Survey, Earth Sciences Report. 2000. 7: 216 (CDROM)

Hein F J, Cotterill D K, Rice R, et al. Subsurface geology of the Athabasca Wabiskaw-McMurray succession: Lewis-Fort McMurray area, northeastern Alberta (NTS 74D/14). Alberta Energy and Utilities Board/Alberta Geol. Survey, Earth Sciences Report. 2006: 61 (CD-ROM)

Hein F J and Dolby G. Regional lithostratigraphy, biostratigraphy and facies models, Athabasca oil sands deposit, northeast Alberta. Rock the Foundation Convention, Canadian Society of Petroleum Geologists (Calgary). 2001. 3: 170-171

Hein F J and Langenberg C W. Reply to discussion of seismic modeling of fluvial-estuarine deposits in the Athabasca oil sands using ray-trace techniques, Steepbank River area, northeastern Alberta. Bulletin of Canadian Petroleum Geology. 2003. 51: 354-366

Langenberg C W, Hein F J, Berhane H, et al. Three-dimensional geometry of fluvial-estuarine oil-sand deposits of the Clarke Creek area (NTS 74D), northeastern Alberta. Alberta Energy and Utilities Board, Alberta Geological Survey, Earth Sciences Report. 2001. 6: 44 (CD-ROM)

Langenberg C W, Hein F J, Lawton D, et al. Seismic modeling of fluvialestuarine deposits in the Athabasca oil sands using ray-tracing techniques, Steepbank River area, northeastern Alberta: Bulletin of Canadian Petroleum Geology. 2002. 50: 178-204

MacGillivray J R, Strobl R S, Keith D A W, et al. Resource characterization of the McMurray Wabiskaw deposit in the Athabasca South Region of Northeastern Alberta. In: Alberta Oil Sands Technology and Research Authority Technical Publication Series. 1992. 7: 68

Moshier S O and Waples D W. Quantitative evaluation of Lower Cretaceous Mannville Group as source rock for Alberta's oil sands: AAPG Bulletin. 1985. 69: 161-172

Mossop G D. Geology of the Athabasca oil sands. Science. 1980. 207(4427): 145-152

Mossop G D and Flach P D. Deep channel sedimentation in the Lower Cretaceous McMurray Formation, Athabasca oil sands, Alberta. Sedimentology. 1983. 30: 493-509

Ranger M J. A Basin Study of the Southern Athabasca Oil Sands Deposit. Ph.D Thesis. University of Alberta. 1994. 290

Ranger M J and Gingras M K. Discussion of seismic modeling of fluvial-estuarine deposits in the Athabasca oil sands using ray-tracing techniques, Steepbank River area, northeastern Alberta. Bulletin of Canadian Petroleum Geology. 2003. 51: 347-353

Riediger C L, Ness S, Fowler M, et al. Timing of oil generation and migration, northeastern British Columbia and southern Alberta - Significance for understanding the development of the eastern Alberta tar sands deposits (abs.). AAPG Annual Convention Official Program. 2001. 10: A168

Rubinstein I and Strausz O P. Thermal treatment of the Athabasca oil sand bitumen and its component parts. Geochimica et Cosmochimica Acta. 1979. 43: 1887-1893

Smith D G. Comparative sedimentology of mesotidal (2 to $4 \mathrm{~m}$ ) estuarine channel point-bar deposits from modern examples and ancient Athabasca oil sands (Lower Cretaceous), McMurray Formation. In: Reinson G E ed. Modern and ancient examples of clastic tidal deposits - A core and peel workshop. Canadian Society of Petroleum Geologists. 1989. 15: 60-65

Vigrass L W. Geology of Canadian heavy oil sands. AAPG Bulletin. 1968. 52: 1984-1999

Wightman D M, Attala M N, Whyne D A, et al. Resource characterization of the McMurray/Wabiskaw deposit in the Athabasca oil sands area: A synthesis. Alberta Oil Sands Technology and Research Authority Technical Publication Series. 1995. 10: 220 